\title{
FORESTRY DIALOGUE FORESTIER
}

Information for Parliamentarians - no. 40, February 1994

Information pour les Parlementaires $-n^{0} 40$, February 1994

\section{The Canadian Institute of Forestry}

The Canadian Institute of Forestry/Institut Forestier du Canada ( $\mathrm{CIF} / \mathrm{IFC}$ ) has been the national voice for forestry professionals for 86 years. Our mission is to advance the stewardship of Canada's forest resources through leadership, professional competence and public awareness. Our membership includes foresters, forest technicians, educators, scientists and others with a professional interest in forestry. We work in government, industry, research, education and consulting and represent the largest professional voice for forestry in Canada.

\section{The Forestry Dialogue}

The CIF/IFC works very closely with the federal government and with all Members of Parliament. We provide this periodic document, the Forestry Dialogue as a way of keeping you informed on topical issues. Previous Dialogues have dealt with topics such as oldgrowth, clearcutting, recycling and many other issues that you may face.

The purpose of the Forestry Dialogue is to give you access to objective scientific information on specific forestry issues. We are available to provide detailed advice and opinion on any issue you may have questions about, and we would be pleased to provide copies of Dialogues on specific issues.

\section{The Speaker's Office}

The CIF/IFC was able to establish an excellent working relationship with the previous speaker, the Honourable John Fraser. Together with the Speaker's Office, we organized the 1991 Parliamentary Forum on Canada's Forests. Each year during National Forest Week (this year it is May 1-7), we co-hosted a reception for MP's with the Speaker, in his chambers.

\section{Other Activities with the House}

The CIF/IFC meets frequently with Ministers responsible for Forestry, Environment, Indian Affairs, Parks, Wildlife and other portfolios that are linked to forestry. We work closely with opposition critics in these areas as well, to ensure that all sides of the debate are as informed as possible. Our previous efforts included input on the Report to Parliament on Canada's Forests, the NDP's efforts on softwood lumber, the Liberal Party's forest policy paper, and the all-party committee on the federal role in forestry. We remain available to work with all MPs to improve forest resource management in Canada.

\section{Other CIF/IFC Activities}

The CIF/IFC also produces several other publications. The major one is our bi-monthly professional journal, The Forestry Chronicle. Our monthly newsletter, The Forestry Update, is a brief monthly summary of events related to the forest industry, environmental issues in forestry and recently released forestry publications. We also produce policy papers such as the recently released "Twenty-Eight Indicators of Sustainable

\section{L'Institut forestier du Canada}

L'Institut Forestier du Canada/Canadian Institute of Forestry (IFC/CIF) est la porte parole des professionnels de la foresterie depuis 86 ans. Notre mission consiste à faire progresser l'intendance des ressources forestières du Canada en assumant un rôle de leader, en démontrant une compétence professionnelle et en sensibilisant le public.

Nos membres comprennent des forestiers, des techniciens forestiers, des enseignants, des chercheurs et autres personnes qui sont intéressées professionnellement par la foresterie. Nous oeuvront au sien des gouvernements, de l'industrie, de la recherche, en éducation et en consultation et nous représentons le groupe professionnel le plus important en foresterie au Canada.

\section{Le dialogue forestier}

L'IFC/CIF collabore étroitement avec le gouvernement fédéral ainsi qu'avec tous les membres du Parlement. Nous distribuons périodiquement ce document, le Dialogue forestier en tant que mesure pour vous garder informer sur des sujets bien précis . Les précédents numéros du Dialogue forestier ont traité des vieilles fôrets, de la coupe à blanc, du recyclage ainsi que de plusieurs autres sujets auxquels vous pourriez faire face. L'objectif du Dialogue forestier est de vous donner accès à une information scientifique objective sur des sujets spécifiques en foresterie. Nous sommes prêt à vous fournir des conseils détaillés ainsi qu'une opinion sur tout sujet sur lequel vous avez des interrogations, et nous serions heureux de vous transmettre des copies des Dialogues publiés sur certains sujets spécifiques.

\section{Le président des Communes}

L'IFC/CIF a été en mesure d'établir une excellente relation de travail avec le précédent président de la Chambre des Communes, L'Honourable John Fraser. En collaboration avec le bureau du président, nous avons organisé en 1991, le Forum parlementaire sur les forêts de Canada qui a coincidé avec la publication du tout premier Rapport au Parlement sur les forêts du Canada. Chaque année au cours de la Semaine nationale des forêts (qui aura lieu cette année du 1-7 mai), nous avons conjointement préparé avec le président, une réception pour les députés fédéraux.

\section{Autres activités avec la Chambre des Communes}

L'IFC/CIF rencontre régulièrement les ministres responsables des Forêts, de l'Environnement, des Affaires indiennes, des Parcs, de la Faune et des autres porte-feuilles rattachés à la foresterie. Nous collaborons également avec les critiques de l'opposition dans ces domaines, de façon à assurer que toutes les parties en place soient aussi bien informées que possible. Nos efforts dans le passé ont couvert également de éléments destinés au Rapport du Parlement sur les forêts du Canada, les démarches du NPD relativement au bois d'oeuvre, le mémoire 
Forestry". All of these publications are available to MPs through subscription. Contact our office for samples and information on how to subscribe.

We at the CIF/IFC welcome you to Ottawa and to the Parliament of Canada. We look forward to working with all MPs and we hope you will enjoy receiving and using the "Forestry Dialogue" and the other publications of the Canadian Institute of Forestry. We would be pleased to respond to requests for information on specific forestry issues.

\section{Progress and Improvement}

25 million seedlings a year

is just the beginning.

For the whole story request a complimentary copy of our new environment report.

\section{CANFQR}

Canadian Forest Products Ltd.

2900 - 1055 Dunsmuir Street PO Box 49420 Bentall Postal Station Vancouver, B.C. V7X 1 B5 Phone: (604) 661-5241 Fax: (604) 661-5235 du Parti Libéral en matière de politique forestière, ainsi que le comité multipartie sur le rôle du fédéral en foresterie.

\section{Autre Activités de l'IFC/CIF}

L'IFC/CIF produit également plusieurs autre publications. La plus importante est le Forestry Chronicle, une revue professionnelle publiée tous les deux mois. Notre bulletin mensuel l'Information forestière, est un court résumé des événements reliés à l'industrie forestière, aux questions environnementales en forestiere et au publications forestières récentes. Nous publions également des mémoires tel ce tout demier sur "Les vingt-huit indicateurs de la foresterie durable".

Toutes ces publications sont disponibles aux députés fédéraux moyennant certains frais. Veuillez contacter notre bureau pour des exemplaires et de plus amples informations sur les mécanismes d'inscriptions.

Les membres de L'IFC/CIF vous souhaitent la bienvenue à Ottawa et au sein du Parlement canadien. Nous ésperons qu'il nous sera possible de travailler avec tous les députés fédéraux et que vous apprécierez et utiliserez le "Dialogue forestier" ainsi que les autre publications de l'Institut Forestier du Canada. Nous demeurons à votre disposition pour répondre à vos requêtes d'information sur tous sujets se rattachant à foresterie.

\section{What has the CIF/IFC Done for you Lately?}

$\square \quad$ Named to the Steering Committee of a National Group charged with the development of criteria and indicators of sustainable forestry in Canada

$\square \quad$ Appeared before the House of Commons Standing Committee on Natural resources to discuss the topic of clearcutting

$\square \quad$ Contacted every university forestry graduate of the past five years who is not a $\mathrm{CIF} / \mathrm{IFC}$ member and invited them to join

$\square \quad$ Initiated a program with the sections to prepare a briefing for each MP on forestry in their riding

$\square \quad$ Began discussions with McLean Hunter for a possible third Silviculture Conference in 1995

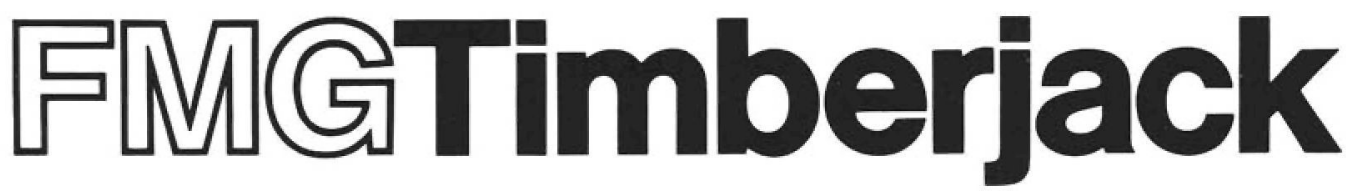

\section{A CIF/IFC Corporate Sustaining Member}




\section{FORESTRY DIALOGUE FORESTIER}

Information for Parliamentarians - no. 41, March 1994

\section{Forestry in Canada}

\section{Forest Area}

Half of Canada's land area is covered by forests. This represents about 10 per cent of the global forest area. Canada is a forest nation.

Over half of our forested area, or 237 million hectares, is described as being suitable for commercial forestry purposes.

Of this 237 million hectares of "commercial" forest, 91 per cent is owned by the public ( 80 per cent provincial, 11 per cent federal), and 9 per cent is privately owned by about 430,000 woodlot owners in Canada. The vast majority ( 77 per cent) of the forest is softwoods (conifers or evergreens) and the balance (23 per cent) is hardwoods or deciduous species.

\section{Environmental Considerations}

Canada's forests comprise a variety of complex ecosystems. They represent extensive biological diversity, help to maintain our water quality, and provide habitat for fish and wildlife. Our forest ecosystems include 131 tree species, over 3000 species of other plants, about 200 species of mammals, 550 species of birds, 90 different amphibians and reptiles and 100,000 species of insects and other invertebrates. Canada's forested watersheds contain about 20 per cent of the world's fresh water.

Although there is considerable debate with respect to global warming, preliminary estimates indicate that Canada's growing forests sequester more carbon than they release. This favourable ratio can be further improved by keeping our forests vigourous and healthy. Canada's forests are also of great cultural significance to Canadians and are an important part of our national heritage.

\section{Economic Considerations}

Forestry is Canada's major source of employment. Direct economic benefits from the forest come in the form of lumber, plywood, particleboard, oriented strandboard, various other solid wood products, pulp, paper, newsprint, Christmas trees, maple syrup, fire wood and dozens of other wood products and byproducts. The forest is also the setting for much of Canada's multi-billion dollar tourism industry and provides recreation, grazing and many other economic activities.

Nearly 900,000 Canadian jobs depend directly or indirectly on the forest sector. This translates into one in fifteen jobs in Canada.

The forest industry represents 15 per cent of Canadian manufacturing. It was valued at almost \$42 billion in 1991 and we exported more than $\$ 23$ billion worth of forest products to the world in 1992. We are the world's largest exporter of forest products, accounting for 21 per cent of total world trade in forest products.

\section{Forestry Activity}

Of the total area of "commercial" forest ( 237 million hectares), 859,362 hectares ( 0.36 per cent) were harvested in
Information pour les Parlementaires - $n^{0} 41$, mars, 1994

\section{La forestière au Canada}

\section{Superficie forestière}

Près de la moitié du territoire canadien est recouvert de forêts. Ces dernières représentent près de $10 \%$ des forêts mondiales. Le Canada est un pays forestier. Plus de la moitié de nos forêts, soit 237 millions d'hectares, est estimée comme pouvant être utilisée à des fins commerciales.

De ces 237 million d'hectares de forêts "commerciales", $91 \%$ sont de propriété publique ( $80 \%$ de juridiction provinciale et $11 \%$, fédérale), et les neuf autres pour-cent constituent des propriétés privées détenues par environ 430000 propriétaires domiciliés au Canada. La plus grand partie de ces forêts (77\%) sont recouvertes de résineux (des conifères) alors que le restant $(23 \%)$ contiennent des espèces à bois franc (des feuillus).

\section{Considérations environnementales}

Les forêts canadiennes comprennent une multitude d'écosystèmes complexes. Elles représentent une importante diversité biologique, et aident à maintenir la qualité de nos eaux, tout en procurant un habitat pour la faune et les poissons. Nos écosystèmes forestiers sont constitués de 131 espèces d'arbres, de plus de 3000 autres espèces de plantes, d'environ 200 espèces de mammifêres, de 550 espèces d'oiseaux, de 90 espèces différentes d'amphibiens et de reptiles et de 100000 espèces d'insectes et autres invertébrés. Les bassins versants boisés du Canada contiennent près de $20 \%$ des eaux douces du monde.

Même en présence d'un important débat relativement au réchauffement climatique, les données préliminaires indiquent que les forêts canadiennes en croissance retiennent plus de carbone qu'elles n'en émettent. Ce ratio positif peut être amélioré en maintenant nos forêts saines et vigoureuses. Les forêts du Canada ont également une signification cuturelle importante aux yeux des Canadiens et constituent un élément important de notre héritage national.

\section{Considérations économiques}

Le secteur forestier constitue l'une des principales sources d'emplois au Canada. Les bénéfices économiques directs tirés des forêts prennent la forme de bois de sciage, de contreplaqué, de panneaux de particules, de panneaux de fibres orientées, ainsi que d'autre produits solides du bois, de pâte, de papier, de papier journal, d'arbres de Noël, de sirop d'érable, de bois de chauffage en plus de douzaines d'autres produits et sous-produits du bois. Les forêts sont également à la base d'une grande partie de l'industrie touristique canadienne évaluée à plusieurs milliards de dollars en plus de servir à des fins de loisir, de pâturage et autres activités économiques.

Près de 900000 emplois au Canada dépendent directement ou indirectement du secteur forestier. Ces emplois équivalent à un emploi sur 15 au Canada. L'industrie forestière représente $15 \%$ du secteur manufacturier du Canada. Elle est évaluée à plus de 42 milliards de dollars pour 1991 et a exporté pour une 
1991. The total harvest in terms of volume in 1991 was 162.1 million cubic meters. This translates into 1.84 jobs per cubic metre and $\$ 258.30$ of value per cubic metre. In 1991 1,574,509 hectares were burned in forest fires (almost twice the area harvested) and 33,830,765 hectares (almost forty times the area harvested!) experienced moderate to severe defoliation from insects.

In 1991, the total area site prepared was 435,430 hectares, the total area planted was 461,408 hectares (with 736.9 million seedlings) and the total area of stand tending was 365,454 hectares. Total forest management expenditures in 1991 were $\$ 2.605$ billion, with 61.7 per cent coming from the federal and provincial governments, and 38.3 per cent from industry.

Forests are being managed on a sustained yield basis to provide important economic benefits while maintaining their ability to contribute to environmental, social and cultural values. With increasing demands on our forests, further refinements in practice are required, as defined in the National Forest Strategy: Sustainable Forests - A Canadian Commitment. The forestry sector has endorsed the strategy. It will require the sustained effort of all the major participants to reach our objectives, including federal and provincial governments, industry, labour, aboriginals, and the many other stakeholders. We have come a long way together. It is essential that we maintain this collective and cooperative effort to achieve sustainability.

\section{Letter / Lettre}

\section{POLITICALLY CORRECT TREE SPECIES}

I have recently been greatly privileged to receive a copy of the memo sent to United States Department of Agriculture Forest Service Personnel pointing out that Pinus sabiniana Dougl. is no longer digger pine, but the politically correct (and perhaps psychologically revealing?) 'grey'. This is because 'digger' is a pejorative term for North American aboriginals (though the few native students in our faculty were hitherto unaware of this apparently esoteric fact). What will be the penalties for transgressors? I eagerly await a follow-up memo. Also I note that Canadian author June Callwood has been expelled from the Canadian Writers Union - it seems that "black sheep" crept into one of her works. Black is of course the pejorative of choice for Africans.

May I suggest, in the interests of our remaining at the forefront of responsible social behaviour, that The Forestry Chronicle sponsor a competition among readers for the most suitable new names of our native tree species such as black walnut, black spruce and black willow? I'll suggest a rather un-pithy 'white challenged cottonwood' for Populus trichocarpa Torr. and Grey. The first prize might be a pair of framed portraits of Queen Victoria and Senator Joseph McCarthy.

And then there are the scientific names! Here's an opportunity for some aspiring young botanist to achieve immortality by suggesting a more decent name for the pine genus.

John G. Worrall

Forest Sciences

Faculty of Forestry

$U B C$ valeur de plus de 23 milliards de dollars de produits forestiers, ce qui représente $21 \%$ du commerce mondial de produits forestiers.

\section{Activités forestières}

Les forêts ont été exploitées sur 859362 hectares en 1991, ce qui équivaut à $0.36 \%$ de la superficie totale des forêts commerciales ( 237 millions d'hectares). La récolte totale en terme de volume en 1991 égale 162.1 millions de mètres cubes. Ce volume représente 1.84 emploi par mètre cube et une valeur de 258.30 \$ par mètre cube. En 1991, 1574509 hectares ont été dévastés par les feux de forêts (près du double de la superficie récoltée) et 33830765 hectares (près de quarante fois la superficie récoltée) ont été modérément à sévérement ravagés par les insectes.

En 1991, une superficie totale de 435430 hectares a fait l'objet d'une préparation de site, 461408 hectares ont été reboisés (au moyen de 736.9 millions de semis) et 365454 hectares ont été entretenus.

Les dépenses totals en aménagement forestier en 1991 atteignaient 2.605 milliards de dollars, dont $61.7 \%$ provenait des gouvernement fédéral et provinciaux, et $38.3 \%$ de l'industrie.

Les forêts sont aménagées sur une base de rendement soutenu dans le but de maintenir à un niveau intéressant les bénéfices économiques qu'on à en retire tout en préservant leur capacités à contribuer aux valeurs environmentales, sociales et culturelles. En vertu des demandes sans croissants exigées de nos forêts, de plus amples ajustements des pratiques forestières sont requis, tels que définis dans La Stratégie nationale sur les forêts: La Durabilité des Forêts, un Engagement canadien. Le secteur forestier a endossé cette stratégie. L'effort soutenu de tous les principaux participants dont les gouvernements fédéral et provinciaux, l'industrie, les syndicats, les autochtones, et plusieurs autres milieux impliqués est requis afin d'atteindre nos objectifs. Nous avons parcouru ensemble un long chemin. Il est essentiel de poursuivre cet effort collectif et ce mouvement coopératif afin d'atteindre la durabilité.

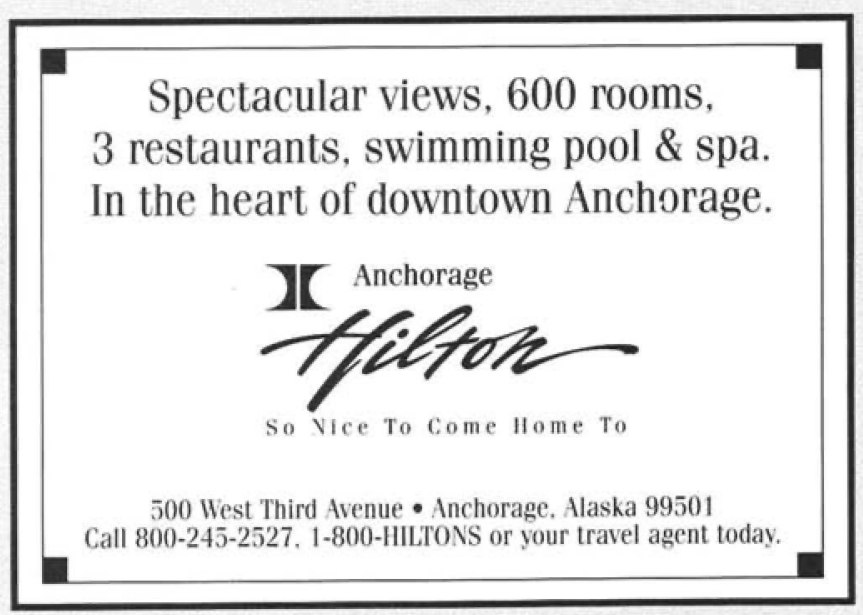

